\title{
CFD SIMULATION OF FLOW FORCE REDUCTION IN HYDRAULIC VALVES
}

\author{
Niko Herakovič, Jožef Duhovnik, Marko Šimic
}

Original scientific paper This paper describes some possible methods for the reduction of the axial static flow forces in hydraulic sliding-spool and small on/off seat valves. These forces increase with the increase in the volume flow and the pressure difference and thus determine higher actuation forces for the control of the valve unit. This results in the necessary use of more powerful actuators for the direct control of hydraulic valves. The topic is therefore very relevant from the energy consumption point of view regarding the actuation of hydraulic valves. To make the use of low-power actuators for the control of directly actuated valves possible also for higher hydraulic power the flow forces acting on the valve piston in the axial direction must be reduced. This paper presents one of the possible solutions with such a design of the hydraulic valve housing and the spool that the flow stream of the fluid through the valve causes minimal axial static forces. The main influential geometry parameters of the sliding-spool and seat valve are defined and analysed in detail using the CFD (Computational Fluid Dynamics) simulation tool Ansys CFX and experimental analysis for the validation of the numerical fluid model of the valve. The results of the research are very promising and prove that the axial component of the flow forces and therefore the necessary actuation force can be reduced significantly just by modifying the geometry of the valve housing and spool. Thus the power consumption of the actuator is minimised and the valve dynamic characteristics are improved at the same time.

Keywords: CFD simulation; experimental analysis; fluid flow forces; geometry optimisation; seat valve; sliding-spool valve

\section{CFD simulacija smanjenja sila protoka fluida u hidrauličnom ventilu}

Izvorni znanstveni članak

Ovaj članak opisuje neke moguće metode za smanjenje statičnih sila protok ulja u hidrauličkom ventilu sa uzdužnim klipom i malim "on/off" sjedežnim ventilom. Sa porastom strujnog toka i razlike tlakova dolazi do povećanja aksijalnih statičnih sila što prouzročava upotrebu viših potisni sila odnosno veću potrošnju energije pri upravljanu ventila. Spomenjeno rezultira obaveznom upotrebom aktuatora veće snage za direktno upravljanje hidrauličkog ventila. Sa stajališta potrošnje energije pri upravljanju ventilom ova tema je veoma važna. Da bi omogućili upotrebu aktuatora niže snage za direktno upravljane ventila s visokim protokom ulja, potrebno je smanjiti aksijale sile koje djeluju na klip u ventilu.Ovaj istraživački rad predstavlja jedno od mogućih rješenja s takvim dizajnom kućišta hidrauličkog ventila i klipa da strujni tok ulja kroz ventil uzrokuje minimalne statične aksijalne sile. Glavni parametri geometrije ventila sa uzdužnim klipom i malim "on/off" ventila su definirani i detaljno analizirani pomoću CFD (Computational Fluid Dynamics) simulacijskoj alata Ansys CFX. Poslije toga provedena je eksperimentalna analiza za validaciju numeričkog modela ventila. Rezultati istraživanja su vrlo obećavajući i dokazuju da aksijalna komponenta sile protoka, a stoga i snaga potrebna za aktiviranje, može se značajno smanjiti samo promjenom geometrije kućišta ventila i klipa. Tako je potrošnja energije za pogon smanjena na minimum, a dinamične karakteristike ventila su poboljšane u isto vrijeme.

Ključne riječi: CFD simulacija; eksperimentalna analiza; hidraulički nasjedni ventil; hidraulički ventil s uzdužnim klipom; optimizacija geometrije; sile protoka fluida

\section{Introduction}

Many successful technical applications nowadays depend on energy consumption and dynamic characteristics of hydraulic drives. Despite the extended possibilities of the mechatronic systems, it will also be very important in the future to pay more attention to the design and construction improvements of individual hydraulic components, especially hydraulic valves, which results in increased efficiency of entire hydraulic system [1]. Valves can be basically classified as noncontinuously operating (e.g., switching and shut-off or on/off valves) and continuously operating valves (e.g., proportional and servo valves) [2].

An electrically direct-controlled valve consists of an electromechanical transducer and of a hydraulic power part. The role of the electromechanical transducer is to convert electrical energy into mechanical energy with output parameters, such as force or position [3]. Because of the limited actuating-force potential of electromechanical actuators, direct control of hydraulic valves using electromechanical actuators is only practical for small nominal sizes of valves where the axial flow forces of the hydraulic fluid flowing through the valve are not too high. When we talk about high dynamic hydraulic drives with a large fluid flow, the actuating-force potential of electromechanical actuators becomes questionable for the direct control of the valves. Some of the disadvantages include high power consumption and weaknesses regarding the dynamic response and instability of the system, among others.

These problems can be tackled with a detailed analysis of the so-called disturbance forces in the valve, which are working against actuator $F_{\text {act }}$ or the control force. They consist of flow forces $F_{\text {flow }}$ with stationary $\left(F_{\text {flow, stat }}\right)$ and dynamic components $\left(F_{\text {flow, dyn }}\right)$, frictional forces $F_{R}$, pressure forces $F_{p}$, inertial (mass) forces $F_{a}$ and spring forces $F_{\text {spring }}$ (Fig. $1 \mathrm{a}$ and b) $[4,5,6,7]$. Force $F_{\text {o- }}$ ring should be taken into account when O-ring seals are used to prevent the external leakage of the on/off valve (Fig. 1b).

The most influential forces, which determine the power of the control actuator for the valve, are flow forces which emerge with a change of direction and/or velocity of the oil flow stream. The valve spool must stay in a balanced state [3], so it is necessary that external reaction forces act on it in the opposite direction from the one in which the axial component of the flow forces acts. For this reason, this component should be kept as small as possible.

In this paper, we therefore present some research efforts for the reduction of the axial component of the flow forces by using the flow-stream abbreviation method. In the first part, we discuss the example of the 
sliding-spool valve, and in the second part of the paper, we describe a small seat on/off valve and present some experimental and CFD simulation results, and comment on the main influential parameters for the flow force reduction.
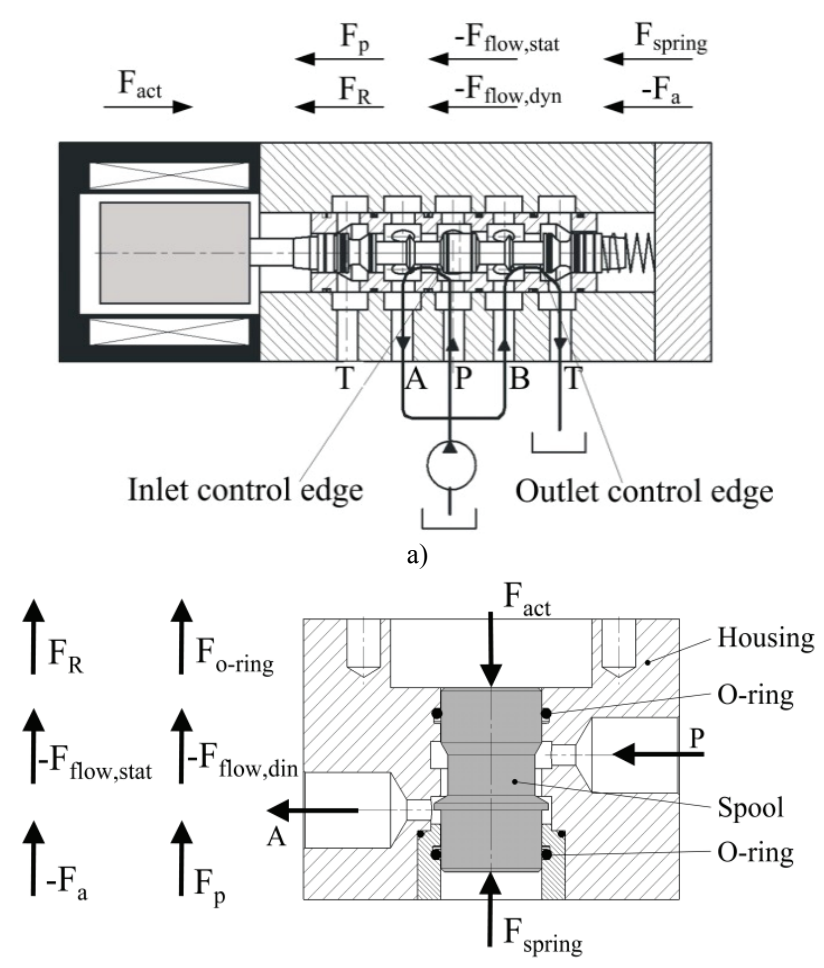

b)

Figure 1 Forces acting on the valve piston in a) sliding-spool valve and b) seat on/off valve

\section{Flow-force reduction methods}

The flow process and the reduction of the flow forces in hydraulic valves have been investigated in numerous research works. Experimental possibilities with two-dimensional (2D) and three-dimensional (3D) flow force reduction methods have been examined by different authors $[3,4,6,7,8,9,10,11]$. The first classification of the suggested techniques was made by Backé [12].

Beside the experimental approach, the flow force reduction can also be done by using analytical and numerical approaches. Some authors use the artificial intelligence method for velocity components prediction [13], others developed new numerical approaches in combination with standard CFD methods to improve the calculation method or to expedite the simulation procedure [14]. Many authors use simplified axisymetrical CFD models $[3,15,16,17]$. The numerical CFD method described in this paper offers practical means for solving many engineering problems concerning the dynamic fluid flow $[15,18,19,20]$.

\subsection{Sliding-spool valve}

Let us consider the stationary operation of a hydraulic sliding-spool valve [4]. It is a 4/3-directional hydraulic proportional sliding-spool valve of nominal size 6 . The valve was designed using the valve spool-socket configuration in a four-chamber design. Some forces, which act on the sliding spool of the valve, are caused by the momentum of the fluid flowing through the valve. The situation is presented as a schematic structure of the inlet and outlet edges of a non-compensated hydraulic valve with a valve spool and a socket (Fig. 2). The metering (control) edge of a sliding spool, which acts as resistance through which the fluid flows into the sliding-spool chamber, is defined as the inlet edge. On the other hand, the metering edge where the fluid leaves the chamber is defined as the outlet edge.

Due to the pressure conditions and according to Bernoulli, an area of lower pressure as well as higher fluid-flow velocity develops in the area of the metering edge. This results in the flow force developing in accordance with the pressure distribution in the control chamber of the sliding spool. This force acts in the closing direction of the sliding spool, which means in the opposite direction to the actuator.

The entry angle of the inlet edge depends on the geometry parameters of the valve, such as the edge rounding of the spool and the housing, and the radial gap between the spool and the housing. It has the value of $\varepsilon_{1}=$ $69^{\circ}$ when taking into consideration the ideal conditions in a valve (the clearance and the rounding radius $=0$ ). At the same time, the valve opening $y$ must be much smaller than the other dimensions of the upstream-lying chamber $[2]$.

The calculation of the flow force is possible by taking into account some simplifications of the law of conservation of momentum for the inlet as well as for the outlet edge. The flow force acting on the sliding spool can be determined by calculating the change of the momentum in the control volume of the sliding-spool chamber $[2,4,21]$, with the assumption that the fluid stream is non-compressible, two-dimensional, free of losses (friction free) and non-rotational.

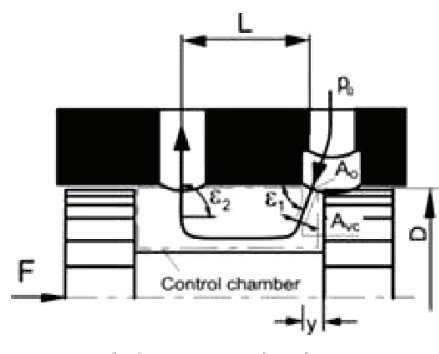

Inlet control edge

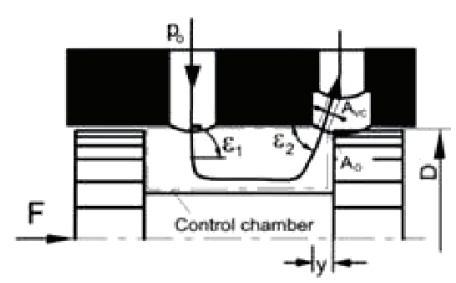

Outlet control edge

Figure 2 Flow forces acting on the valve piston [4]

The stationary share of the flow force for the inlet edge can be calculated from the axial momentum component using the Eq. (1):

$$
F_{a x_{\text {stat }}}=\rho \cdot Q \cdot\left(v_{2} \cdot \cos \varepsilon_{2}-v_{1} \cdot \cos \varepsilon_{1}\right) .
$$


The non-stationary share of the flow force, which describes the force necessary to accelerate the fluid mass in the sliding-spool chamber, can be calculated using the length $l$ of the accelerated oil quantity in the control volume of the sliding-spool chamber:

$$
F_{a x_{\text {instat }}}=-\rho \cdot l \cdot \frac{\mathrm{d} Q}{\mathrm{~d} t} .
$$

The mean velocity $v$ at the stream edge depends on the oil density $\rho$ and the pressure difference $\Delta p$ :

$$
v=\sqrt{\frac{2}{\rho} \cdot \Delta p} .
$$

The volume flow $Q$ depends on the contraction coefficient $\alpha_{D}$, the opening cross-section $A_{\mathrm{o}}$ and on the fluid-flow velocity $v$ :

$Q=\alpha_{D} \cdot A_{\mathrm{o}} \cdot v$,

where $A_{\mathrm{o}}=\pi \cdot D \cdot y$ and $\alpha_{D}=A_{v c} / A_{\mathrm{o}}$.

$A_{\mathrm{o}}$ is the control edge opening cross-section $\left(\mathrm{m}^{2}\right)$

$A_{v c}$ is the fluid-flow cross-section $\left(\mathrm{m}^{2}\right)$.

\subsection{Small on/off seat valve}

The area of flow forces of a seat valve (see Fig. 1b) can be divided into two separate valve areas - the inlet and outlet control volumes (Fig. 3).

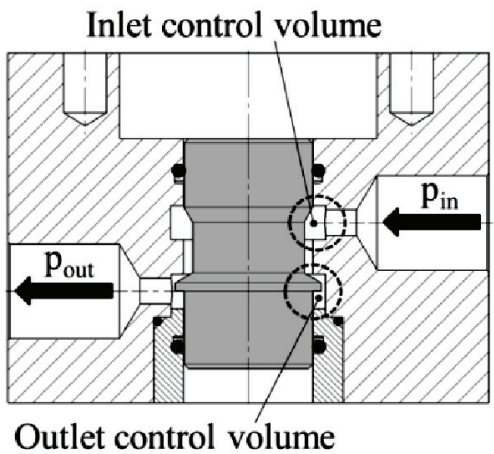

Figure 3 Hydraulic on/off valve, inlet and outlet control volumes

The inlet control volume (see Fig. 4a) acts like a high pressure chamber with low fluid velocity at the entrance. In the first stage of the operation, the fluid is guided by the inlet socket with the height $h_{1}$ and the inlet angle $\alpha$ and it accelerates through the housing/spool gap. At this stage, the fluid velocity is defined by the size of the gap, $r_{1}$. The dynamic flow forces acting on the spool surfaces are determined by the flow velocity in combination with the inlet angle $\alpha$ and the seat angle $\beta$.

The size of the valve opening $y$ at the metering edge defines the second acceleration of the fluid. The fluid flows with high velocity into the outlet control chamber (see Fig. 4b) where three-dimensional turbulent flow streams create additional flow forces acting on the spool.The fluid streamlines and the flow forces depend mainly on the shape and the dimensions of the valve seat (parameters $h_{2}$ and $r_{2}$ ) as well as on the valve housing.

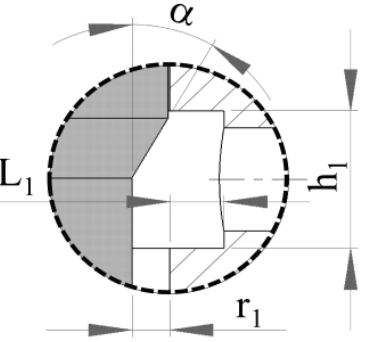

a)

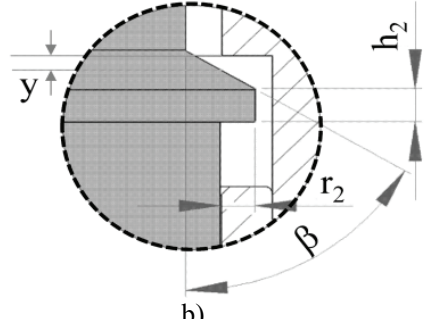

b)
Figure 4 Control volumes of the hydraulic on/off valve: a) inlet and b) outlet

In this research, the inlet control chamber and the inlet angle $\alpha$ of the spool have been analysed in detail. It was concluded that in order to achieve a proper crosssection area at maximal spool stroke and to ensure no leakage for a given preloaded spring force the valve seat angle has to be $\beta=60$ degrees [17] (see Fig. 4b). A hydraulic seat valve has been guided through the O-ring seals without direct contact with the housing of the valve and with extremely small spool displacement $y$ up to 0,1 $\mathrm{mm}$.

\section{CFD simulation approach}

The calculation of the pressure distribution and flow streams in both, the sliding-spool and the small seat valves was performed using the CFD simulation tool Ansys 12 . The primary goal of the CFD simulation is to get the appropriate CFD simulation models for further optimization and the development of new valves. In comparison with the experimental approach, which is time-consuming and expensive due to the need to change the geometry of the valve to create a new prototype, the CFD simulation offers a relatively inexpensive and less time-consuming approach. To get the most appropriate or realistic CFD model of the fluid flow through the valve we must know in detail all the parameters which have a decisive influence on the fluid flow through the valve and thus the current fluid flow force. Therefore, it is necessary to properly define the geometry, mesh parameters, boundary conditions, etc., in the valve and determine the type of the fluid flow through the valve at different openings of the spool by calculating the Reynolds number in the tubes by using Eq. (5) and (6).

$$
\begin{aligned}
& \operatorname{Re}=\frac{\rho \cdot v_{f} \cdot d}{\mu}, \\
& v_{f}=\frac{Q}{A_{Q}},
\end{aligned}
$$

where $v_{f}$ and $d$ are the representative velocity and diameter of the inlet channel of the valve, $\mu$ is the dynamic viscosity of the fluid, $\rho$ represents the fluid density, $Q$ is the fluid flow and depends on the opening of the valve, and $A_{Q}$ represents the cross-section of the inlet channel of the valve flow. 
For a sliding-spool valve of nominal size 6 , with the inlet channel diameter $d=6,3 \mathrm{~mm}$ and with the dynamic viscosity of the fluid $\mu=0,0117 \mathrm{~Pa} \cdot \mathrm{s}$, the Reynolds numbers are $\operatorname{Re}=14400$ for the valve opening $y=0,6$ $\mathrm{mm}$ and $\mathrm{Re}=2880$ for the valve opening $y=0,1 \mathrm{~mm}$, respectively. Because in the internal flows the turbulent flow occurs at high Reynolds numbers ( $R e \geq 2320)$, the turbulent flow in our case occurs in the valve in both cases: at small openings where $y=0,1 \mathrm{~mm}$ we get a transition from the laminar to turbulent flow, and at large openings where $y=0,6 \mathrm{~mm}$ the turbulent flow further intensifies.

For a small on/off valve with the maximal flow rate of $20 \mathrm{l} / \mathrm{min}$ at pressure difference $\Delta p=25$ bar, with the inlet channel diameter $d=4 \mathrm{~mm}$ and with the dynamic viscosity of the fluid $\mu=0,0117 \mathrm{~Pa} \cdot \mathrm{s}$, the Reynolds numbers are $\operatorname{Re}=7580$ for the valve opening $y=0,1 \mathrm{~mm}$ and $\operatorname{Re}=760$ for the valve opening $y=0,01 \mathrm{~mm}$, respectively. The internal flow varies from pure laminar (at small openings) to high turbulent flow according to the Reynolds number. The transition from the laminar to turbulent flow occurs at valve opening $y=0,4 \mathrm{~mm}$, where Reynolds number is $\mathrm{Re}=2280$.

In this context, it is necessary to consider different models of fluid flow through the valve offered by the CFD simulation program (Fig. 5). Especially for smaller openings of the valve piston where the situation in the fluid flow through the opening is the most critical, the turbulence model "Shear-Stress Transport SST $k-\omega$ " and the Ansys CFX simulation tool have been proven to give the best results for a small on/off seat valve. The ShearStress Transport SST $k-\omega$ model presents the most sophisticated model of the Ansys CFX which allows us the advanced near-wall treatment even for grids with reduced near-wall spacing. That makes the model more robust and accurate compared to the other standard turbulence models $k-\varepsilon$ and $k-\omega$.The turbulence transition model " $k-k l-\omega$ " used in Ansys FLUENT has been proven to give the best results for the sliding-spool valve [22, 23]. They are both based on the finite-volume method for solving the complete, incompressible Reynolds-averaged Navier-Stokes equations (RANS)[24].

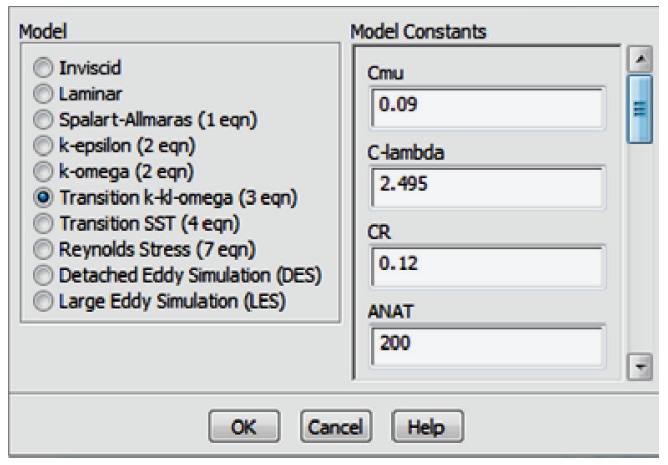

Figure 5 Different models of fluid flow

\subsection{Theoretical description of the turbulence models}

The turbulence model "SST $k-\omega$ " is based on two transport equations, Eq. (7) and (8), where the turbulence kinetic energy $k$ and the specific dissipation rate $\omega$ are computed [24]. The model works so that it uses the turbulence/frequency-based model $(k-\omega)$ at the wall and $k-\varepsilon$ in the bulk flow. A blending function ensures a smooth transition between the two models.

$$
\begin{aligned}
& \frac{\partial}{\partial t}(\rho k)+\frac{\partial}{\partial x_{i}}\left(\rho k u_{i}\right)=\frac{\partial}{\partial x_{j}}\left[\left(\mu+\frac{\mu_{t}}{\sigma_{k}}\right) \frac{\partial k}{\partial x_{j}}\right]+G_{k}-Y_{k}+S_{k} \\
& \frac{\partial}{\partial t}(\rho \omega)+\frac{\partial}{\partial x_{i}}\left(\rho \omega u_{i}\right)=\frac{\partial}{\partial x_{j}}\left[\left(\mu+\frac{\mu_{t}}{\sigma_{\omega}}\right) \frac{\partial \omega}{\partial x_{j}}\right]+G_{\omega}-Y_{\omega}+D_{\omega}+S_{\omega}
\end{aligned}
$$

In these equations, $G_{k}$ represents the generation of the turbulence kinetic energy due to mean velocity gradients. $G_{\omega}$ represents the generation of $\omega . Y_{k}$ and $Y_{\omega}$ represent the turbulence dissipation of $k$ and $\omega . D_{\omega}$ represents the crossdiffusion modification term to blend $k-\varepsilon$ and $k-\omega$ models together. $S_{k}$ and $S_{\omega}$ are user-defined source terms. $\sigma_{k}$ and $\sigma_{\omega}$ are the Prandtl numbers for $k$ and $\omega$, respectively. Turbulent viscosity $\mu_{t}$ is calculated as follows [24]:

$\mu_{t}=\frac{\rho k}{\omega}\left[\max \left(\frac{1}{a^{*}, \frac{S \cdot f_{2}}{b_{1} \omega}}\right)\right]^{-1}$,

where $S$ is the strain rate magnitude, $a^{*}$ is the coefficient which damps the turbulent viscosity causing a lowReynolds-number correction, $f_{2}$ is the blending function, while $b_{1}$ is a constant.

The model constants, which are used to calculate the transport equations and their components, are: $\sigma_{k, 1}=$ $1,176, \sigma_{\omega, 1}=2, \sigma_{k, 2}=1, \sigma_{\omega, 2}=1,168, b_{1}=0,31, \beta_{i, 1}=$ 0,075 and $\beta_{i, 2}=0,0828$.

The turbulence transition model " $k-k l-\omega$ " is used to predict the boundary layer development and calculate the transition onset, and it is based on three eddy-viscosity type transport equations, Eq. (10), (11) and (12), where the turbulent kinetic energy $k_{T}$ and the inverse turbulent time scale $\omega$ are computed [24].

$$
\begin{aligned}
& \frac{D k_{T}}{D t}=P_{K_{T}}+R+R_{N A T}-\omega k_{T}-D_{T}+ \\
& +\frac{\partial}{\partial x_{j}}\left[\left(v+\frac{\alpha_{T}}{\alpha_{k}}\right) \frac{\partial k_{T}}{\partial x_{j}}\right], \\
& \frac{D k_{L}}{D t}=P_{K_{L}}-R-R_{N A T}-D_{L}+\frac{\partial}{\partial x_{j}}\left[v \frac{\partial k_{L}}{\partial x_{j}}\right] \\
& \frac{D \omega}{D t}=C_{\omega 1} \frac{\omega}{k_{T}} P_{K_{T}}+\left(\frac{C_{\omega R}}{f_{W}}-1\right) \frac{\omega}{k_{T}}\left(R+R_{N A T}\right)- \\
& -C_{\omega 2} \omega^{2}+C_{\omega 3} f_{\omega} \alpha_{T} f_{W}{ }^{2} \frac{\sqrt{k_{T}}}{d^{3}}+\frac{\partial}{\partial x_{j}}\left[\left(v+\frac{\alpha_{T}}{\alpha_{\omega}}\right) \frac{\partial \omega}{\partial x_{j}}\right] .
\end{aligned}
$$

In Eq. (10), (11) and (12), $P_{k_{T}}$ represents the turbulence production by turbulent fluctuations, $P_{k_{L}}$ is the production of laminar kinetic energy by large scale turbulent fluctuations, $D_{T}$ and $D_{L}$ represent the near-wall 
dissipation, $R$ represents the averaged effect of the breakdown of stream-wise fluctuations into turbulence during bypass transition, $R_{N A T}$ is the natural transition production which considers the breakdown to turbulence due to instabilities, $f_{\omega}$ is the damping in a turbulent boundary layer and depends on turbulent and effective scale lengths, and $\alpha_{T}$ represents the turbulent scalar diffusivity.

The model constants, which are used to calculate the transport equations and their components in the $k-k l-\omega$ transition model, are [24]: $A_{0}=4,04 ; A_{S}=2,12 ; A_{v}=6,75$; $A_{B P}=0,6 ; A_{N A T}=200 ; A_{T S}=200 ; C_{B P, \text { crit }}=1,2 ; C_{N C}=0,1 ;$ $C_{N A T, \text { crit }}=1250 ; C_{I N T}=0,75 ; C_{T S, \text { crit }}=1000 ; C_{R, N A T}=0,02$; $C_{11}=3,4 \times 10^{-6} ; C_{12}=1 \times 10^{-10} ; C_{R}=0,12 ; C_{\alpha, \theta}=0,035$ $C_{S S}=1,5 ; C_{\tau, 1}=4360 ; C_{\omega 1}=0,44 ; C_{\omega 2}=0,92 ; C_{\omega 3}=0,3 ;$ $C_{\omega R}=1,5 ; C_{\lambda}=2,495 ; C_{\mu, \text { std }}=0,09 ; P r_{\theta}=0,85 ; \sigma_{k}=1$, and $\sigma_{\omega}=1,17$.

To guarantee successful further optimization and the development of valves the CFD model of fluid flow must be built in a way that the simulation results will reflect the real situation in the test valve. Therefore, any CFD model must be also verified with the experimental results of a real model of the valve. The CFD simulation model whose simulation results are the closest to the experimental results regarding the parameter values is then used in further optimization and the development of the valves.

\subsection{Modelling of the sliding-spool valve}

The main influential elements of the sliding-spool valve that are optimized in this research - the valve socket and the valve spool -, are presented in Fig. 6. The geometry of the sliding spool depends on the length of the valve body and the valve socket, on the width of the inner circumferential grooves or the distance between the control edges, as well as on the control-edge geometry.
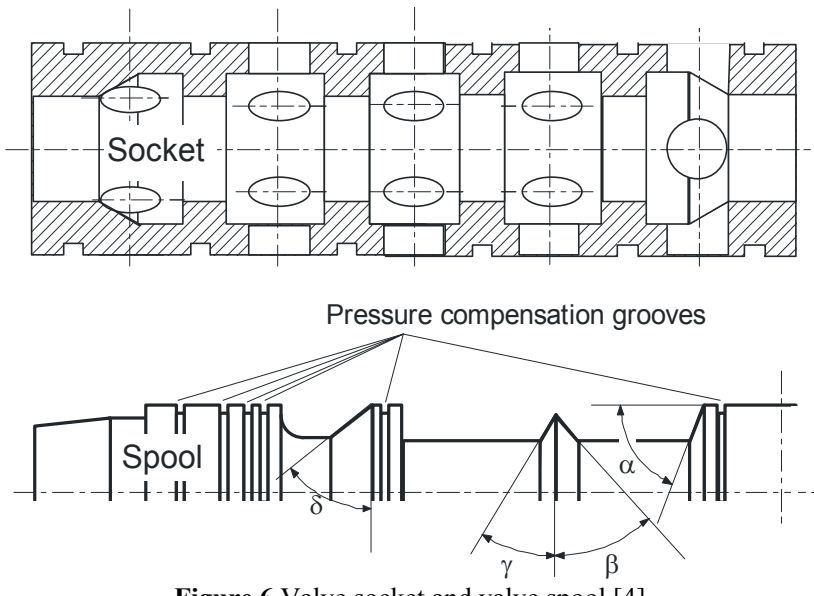

Figure 6 Valve socket and valve spool [4]

The flow-force reduction of the sliding spool is the result of a combination of the angles Alpha $(\alpha)$ and Beta $(\beta)$, influencing the inlet control edge, as well as Gamma $(\gamma)$ and Delta $(\delta)$, influencing the outlet control edge (Fig. $6)$. To get the optimal flow-force compensation it is necessary to analyse different sliding-spool geometries and the combination of the above-mentioned angles. The valve with its specific geometrical features and the detailed research of the experimental optimization of the flow forces in the valve have been discussed in article [4] in which all the details of the valve are presented.Different geometries of five differently designed sliding spools, which have been experimentally analysed in the aforementioned research, are presented in Tab. 1.

But in the mentioned article, the CFD simulation of flow forces in the valve was not conducted. Therefore, in this study, we refer to the aforementioned article and upgrade the research with the CFD modelling and simulation of the flow of forces in the same sliding-spool valve.

Table 1 Valve pistons with the angle geometry [4]

\begin{tabular}{|c|c|c|c|c|}
\cline { 2 - 5 } \multicolumn{1}{c|}{} & \multicolumn{4}{c|}{ Angle } \\
\hline Spool No. & $\alpha / /^{\circ}$ & $\beta /^{\circ}$ & $\gamma /{ }^{\circ}$ & $\delta /^{\circ}$ \\
\hline 1 & 60 & 30 & 30 & 30 \\
\hline 2 & 30 & 40 & 60 & 45 \\
\hline 3 & 30 & 50 & 60 & 60 \\
\hline 4 & 70 & 20 & 20 & 45 \\
\hline 5 & 75 & 15 & 15 & 60 \\
\hline
\end{tabular}

To start the modelling of the fluid flow through the sliding-spool valve, first, the 3D model of the fluid through the whole valve (direction of the flow $\mathrm{P} \rightarrow \mathrm{A} \rightarrow \mathrm{B} \rightarrow \mathrm{T})$ must be made with the use of any 3D modeller (Fig. 7a). Also, the boundary conditions for the inlet and the outlet of the fluid in the 3D fluid model must be carefully defined - black arrows in Fig. 7b [22].

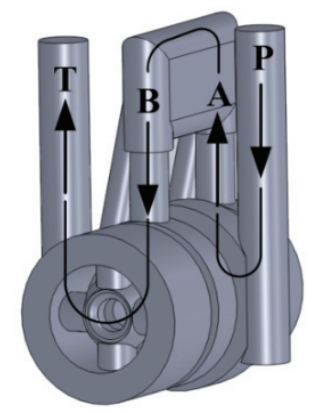

a)

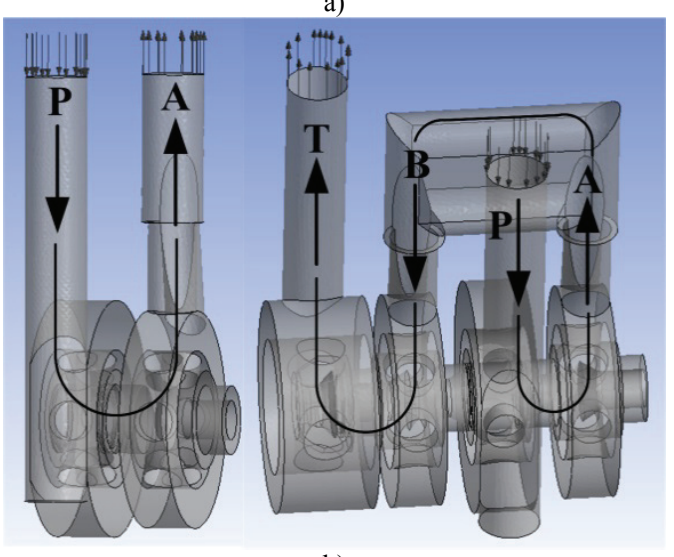

b)

Figure 7 Fluid model: a) 3D model of the fluid through the whole valve, b) boundary conditions of the fluid model [22]

In the next very important step, it is necessary to mesh the fluid model properly. The number and the shape of the meshed elements influence significantly the speed (indirectly the CPU time), accuracy and the regularity of 
the computed results. For computational purposes, the model is therefore meshed using irregular elements required to get the appropriate fine resolution of the mesh (enlarged mesh density) at the most critical regions and surfaces (especially at the high velocity ones), at the edges, at the inlet and outlet ports, in the swirl chambers and at the inflated boundary conditions (Fig. 8a). At the longer annular tubular surfaces, where pressure drops and increases appear, the surface must be inflated with many annular prismatic elements across the whole length of the tube (Fig. 8b).

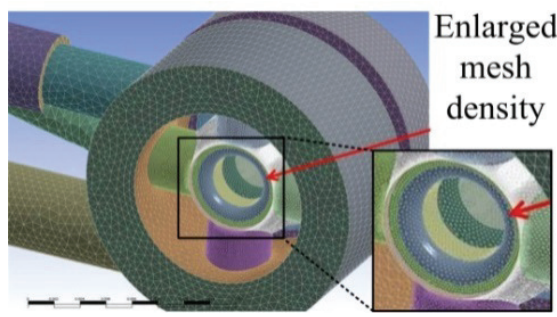

a)

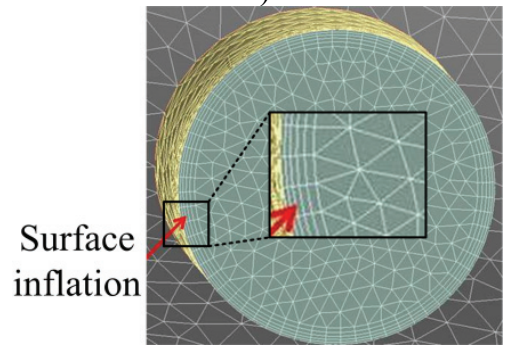

b)

Figure 8 Mesh optimization: a) Increased density of the mesh at the critical surfaces, b) inflation of the mesh at the longer tubular annular surfaces [22]

Table 2 The CFD fluid model settings for the sliding-spool valve

\begin{tabular}{|l|l|}
\hline $\begin{array}{l}\text { Meshing (see } \\
\text { Fig. 8a and } \\
8 \mathrm{~b})\end{array}$ & $\begin{array}{l}\text { Irregular mesh (tetrahedrons, prisms, pyramids), fine } \\
\text { resolution (increased mesh density) at all critical } \\
\text { surfaces (metering edges, inlet and outlet ports, swirl } \\
\text { chambers etc.), approximately 1 million mesh elements } \\
\text { (max 2,9 million). }\end{array}$ \\
\hline $\begin{array}{l}\text { Fluid } \\
\text { parameters }\end{array}$ & $\begin{array}{l}\text { Single-phase flow, no cavitations, mineral oil ISO VG } \\
32 \text { at } 40^{\circ} \mathrm{C}\left(\text { density } \rho=840 \mathrm{~kg} / \mathrm{m}^{3}, \text { dynamic viscosity }\right. \\
\mu=0,0117 \mathrm{~kg} / \mathrm{m} \mathrm{s}, \mathrm{specific} \text { warm capacity } c=2100 \\
\left.\mathrm{~J} /(\mathrm{kg} \cdot \mathrm{K}), \text { molar mass } m_{\mathrm{m}}=495,5 \mathrm{~g} / \mathrm{mol}\right) \text { etc. }\end{array}$ \\
\hline $\begin{array}{l}\text { Boundary } \\
\text { conditions }\end{array}$ & $\begin{array}{l}\text { Static pressure at inlet } p_{\text {in }}=25 \mathrm{MPa} \text { and outlet } p_{\text {out }}=15 \\
\mathrm{MPa}, \Delta p=10 \mathrm{MPa}, \text { no slip wall, smooth wall, volume } \\
\text { fraction of oil at inlet }=1 .\end{array}$ \\
\hline $\begin{array}{l}\text { Simulation } \\
\text { type }\end{array}$ & Steady-state simulation at discrete spool openings $y$. \\
\hline $\begin{array}{l}\text { Turbulence } \\
\text { model }\end{array}$ & Turbulent model $k-k l-\omega$. \\
\hline
\end{tabular}

The fluid parameters selection for the simulation model is given in Tab. 2. The number of all the meshing elements for the simulation has been chosen to be optimal at approximately 1,6 million. A higher number of meshing elements, up to 2,9 million elements, has shown that the simulation results have not been considerably improved, but the simulation time has been considerably longer.

When taking into consideration the abovementioned measures, especially with the increased mesh density in the area of the swirl chamber and at the inlet or outlet channels, we get the appropriate fluid flow through the entire valve with a clearly recognized swirling of the fluid flow in the swirl chambers (Fig. 9).

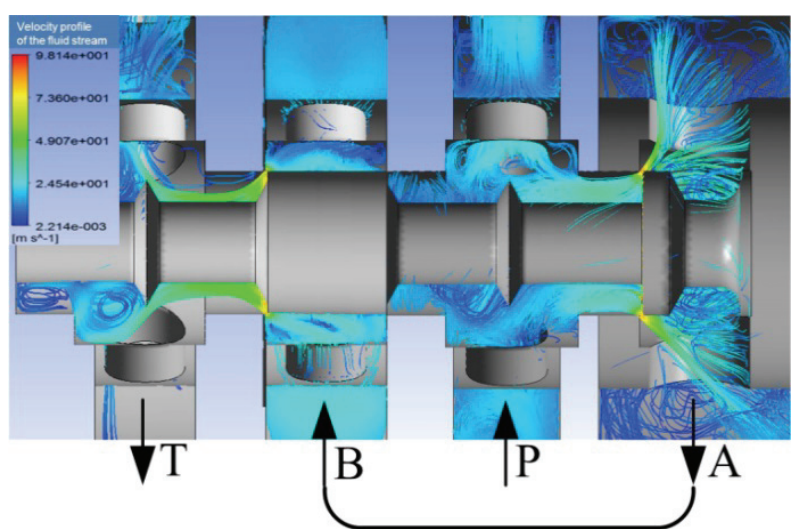

Figure 9 The fluid flow through the entire valve with the swirling of the fluid in the swirl chambers

\subsection{Modelling of the seat valve}

The valve model and fluid model of an on/off valve with $0,1 \mathrm{~mm}$ of maximal opening gap is presented in Fig. $10 \mathrm{a}$ and $10 \mathrm{~b}$. Static pressure compensation is achieved by creating equal areas inside the inlet $\left(A_{1}\right.$, Fig. 10b) and outlet $\left(A_{2}\right.$, Fig. $\left.10 \mathrm{~b}\right)$ valve chambers.
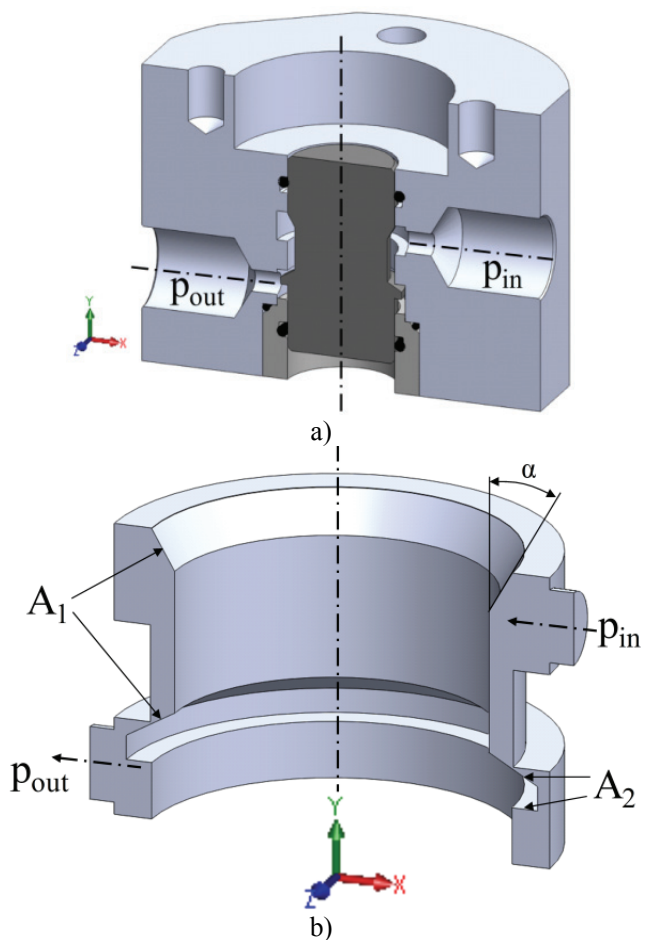

Figure 10 Hydraulic valve: a) 3D model of the valve, b) 3D model of the fluid

The dynamic flow forces are reduced by modifying the spool geometry (inlet angle $\alpha$ ). Six different inlet angles (as shown in Tab. 3 ) are simulated and analysed at ten different openings $y(0,01 ; 0,02 ; 0,03 ; 0,04,0,05 ; 0,06$; 0,07; 0,08; 0,09 and 0,1 mm).

For computational purposes, this model, too, is mashed using irregular elements required for the increased mesh density of the orifice region and the inflated boundary condition at the high velocity surfaces. The complex geometry of fluid models, such as the fluid model of a hydraulic on/off valve, is simulated by using SST $k-\omega$ turbulence model rather than using the standard $k-\varepsilon$ or $k-\omega$ models [20]. 
Table 3 Section of the fluid model with different spool inlet angle $\alpha$
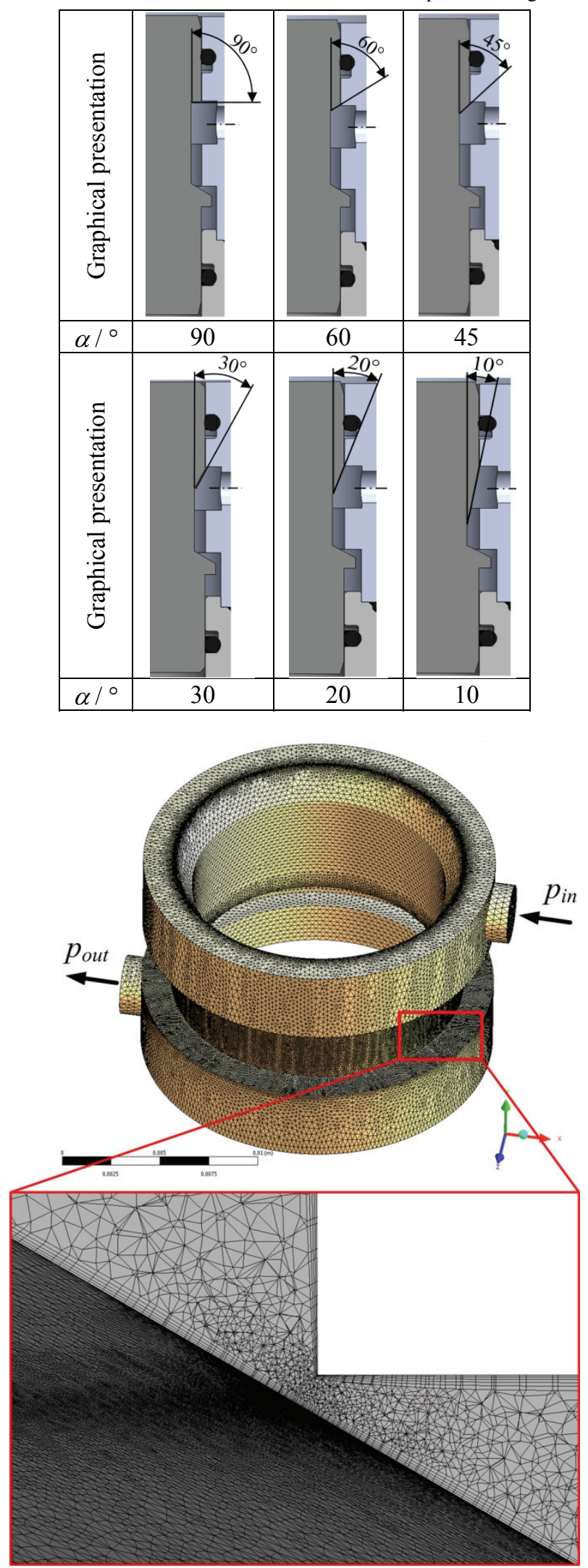

Figure 11 3D mesh model of the fluid

The mesh model and the detail view of the metering edge cross-section are presented in Fig. 11. The mesh parameters are the same as presented in Tab. 2. Fine resolution is set at the surface and control edge of the orifice opening gap which results in approximately 2 million mesh elements. Also the same fluid parameters and the type of the simulation presented in Tab. 2 are used to perform the simulation for the small on/off valve.

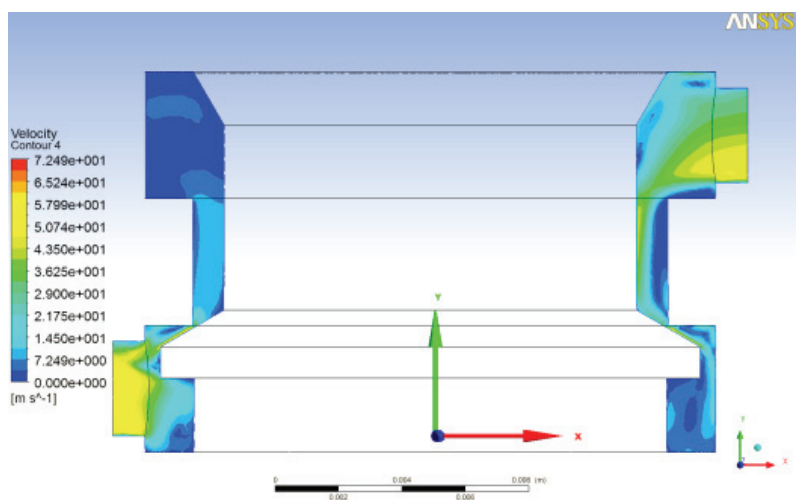

a) Velocity profile

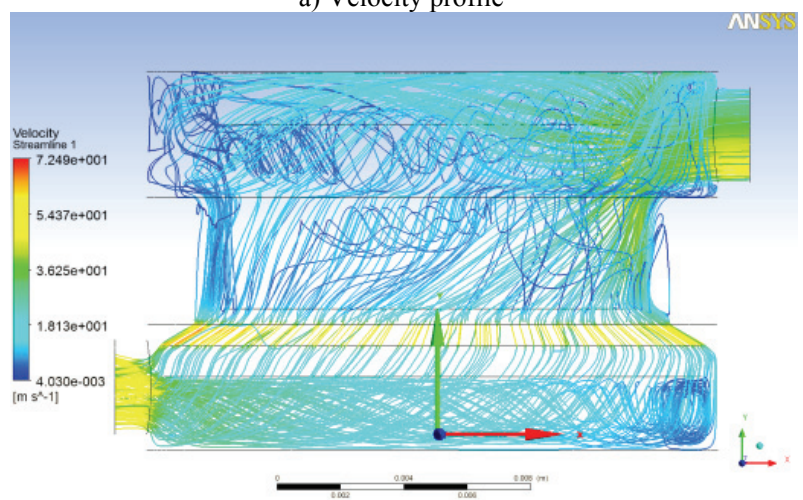

b) Streamline profile

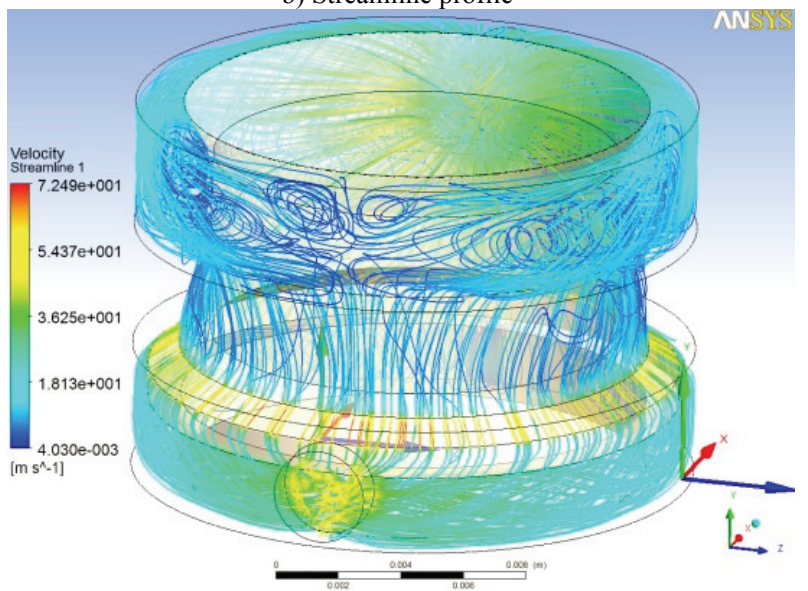

c) Flow direction around the spool

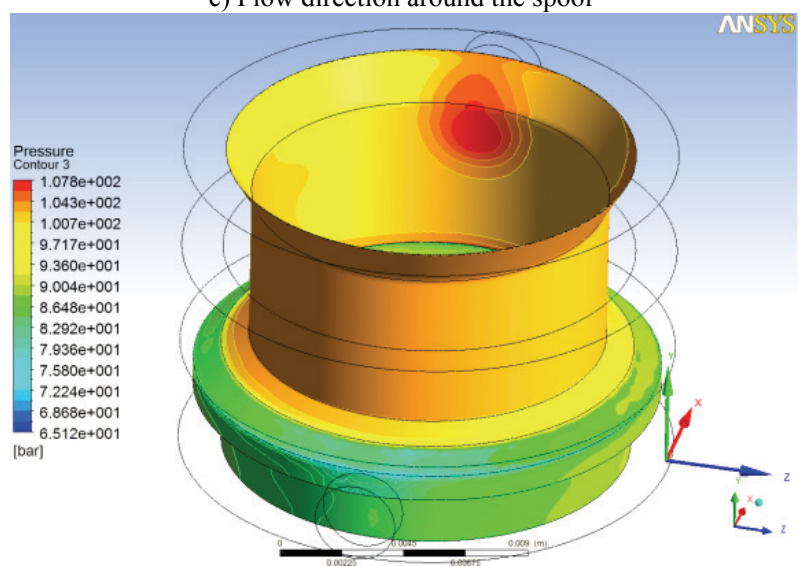

d) Pressure distribution on spool surface Figure 12 CFD analysis 
According to the valve working conditions and the type of the valve the boundary conditions are set as follows:

- Static pressure at inlet $p_{\text {in }}=10 \mathrm{MPa}$.

- Static pressure at outlet $p_{\text {out }}=7,5 \mathrm{MPa}$.

- Pressure difference $\Delta p=2,5 \mathrm{MPa}$.

- No slip wall, smooth wall, volume fraction of oil at inlet $=1$.

The density and dynamic viscosity of the fluid remain constant based on the constant inlet pressure, pressure difference and the temperature. Otherwise the new values of fluid density and dynamic viscosity should be calculated at the given pressure and temperature [25]. The most accurate results are achieved by using the $k-\omega$ based shear-stress-transport (SST) turbulence model.

Since the flow forces in the seat valve are defined by the flow stream direction and flow velocity, the velocity profile (see Fig. 12a) and streamlines (see Fig. 12b) at the inlet chamber had to be considered in the CFD analysis. The analysis shows that a high velocity profile leads to local pressure increase, especially in the areas where the fluid changes its direction around the circumference of the spool surface (Fig. 12c and Fig. 12d). The velocity profile in the inlet angle area is around $(20 \div 25) \mathrm{m} / \mathrm{s}$. The axial component of the flow stream has a direct impact on the spool surface and could lead to the closing of the spool. The inlet chamber becomes a turbulent flow pocket where the fluid acts on the spool surface in a positive axial direction $+y$. The flow goes through the contraction gap toward the metering edge. This creates a jet-guiding laminar flow with increased velocity, and the viscous friction forces act on the spool surface in a negative axial direction $-y$.

\section{Experimental verification and results}

In the extensive experimental survey of the slidingspool valve [4], the non-compensated valve has been compared with the valve with reduced flow forces. The reduction of flow forces has been thoroughly investigated on each metering edge of the sliding spool separately as well as on the entire valve. Finally, an optimal spoolvalve-socket configuration with the sliding spool $\mathrm{Nr} .5$ (see Tab. 1) and with the modified socket has been found. This combination shows significantly better results compared to the non-compensated valve with clearly reduced maximum flow forces and with very convenient flow-force characteristics. The experimental setup has also been described very thoroughly. In this paper, we will use the experimental results of the survey presented by Herakovič [4] for the verification of the CFD simulation results for the entire valve.

In Fig. 13, the CFD simulation results are compared with the experimental results for the optimal spool-valvesocket configuration only. According to the survey [4], the pressure drop through the entire valve is $\Delta p=10$ $\mathrm{MPa}$. At the valve inlet, the supply pressure is $p=25$ $\mathrm{MPa}$, and at the valve outlet the outlet pressure is $p=15$ $\mathrm{MPa}$. The conditions were the same for the experimental analysis as well as for the CFD simulation.

As it can be seen from the results in Fig. 13, the CFD simulation and the experimental results coincide to a great extent. The average deviation between the measured and the simulation curves is around $6,5 \%$. With this experimental verification of the CFD simulation model, we can conclude that the exiting CFD model of the sliding-spool valve can be used for further optimization and the development of a new valve. We can see from these results and the survey that the simulation parameters, including boundary conditions and meshing density, are well defined. Only at larger valve openings above $0,35 \mathrm{~mm}$, the meshing density and the different turbulence models should be further investigated to get even better and more reliable results.

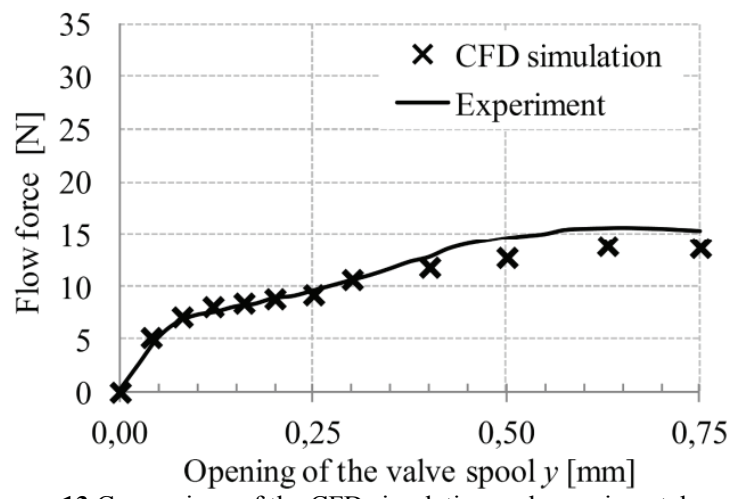

Figure 13 Comparison of the CFD simulation and experimental results of the flow force through the entire valve (P-A-B-T), $\Delta \mathrm{p}=10 \mathrm{MPa}$

For the seat valve, the results of the computational simulation of the flow force compensation are also evaluated by being compared with the results obtained by an experimental investigation carried out in the context of this research. The test rig used for that purpose is shown in Fig. 14. An adjustable device is used to move the spool to a precise position. The spool stroke step is $0,01 \mathrm{~mm}$ with the maximum value of $0,1 \mathrm{~mm}$. The force is measured during the spool stroke by using a force sensor. The inlet and outlet pressures are measured by using pressure sensors to control the constant pressure difference.

For measuring the flow rate, the gear-measuring motor VSI $1 / 16$ EPO $12 \mathrm{~V}-32 \mathrm{~W} 15 / 410 \ldots 28 \mathrm{~V}$ DC from the company VSE was used. The pressure sensors (company: Kistler, Type: 4075A500, range: $0 \div 50 \mathrm{MPa}$ ) for measuring the pressures $p_{\text {in }}$ and $p_{\text {out }}$ were mounted directly on the tested valve. The axial force was measured using a force sensor from the company Burster Präzisionalmeßtechnik, type $8523-500 \mathrm{~N}$, range $\pm 500 \mathrm{~N}$. The exact spool position was measured using an Eddycurrent sensor Micro Epsilon EPU05.

An experimental investigation was performed for flow force characteristics versus spool stroke. Fig. 15 represents the characteristics of the pure flow force, without considering the forces necessary for the deformation of the elastic elements in the valve.

Fig. 16 (a to g) shows the measured flow force results compared with the simulation results for different inlet angles. It is evident that the simulated flow force curve coincides with the measured flow force curve to a great extent. The average deviation between the measured and the simulation curves is around $3 \%$. As shown, the flow force increases with the increase of the spool stroke. 


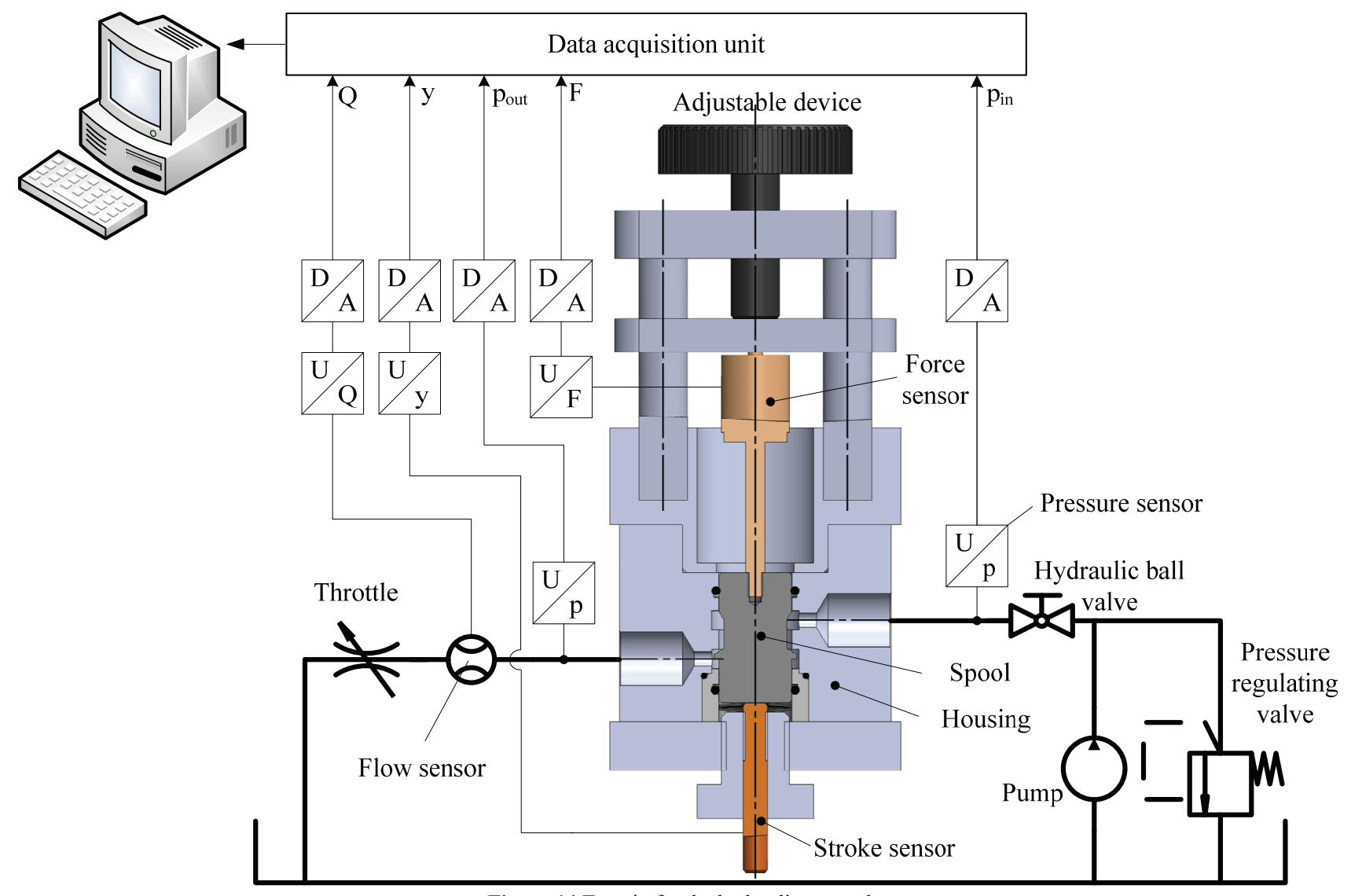

Figure 14 Test rig for the hydraulic seat valve

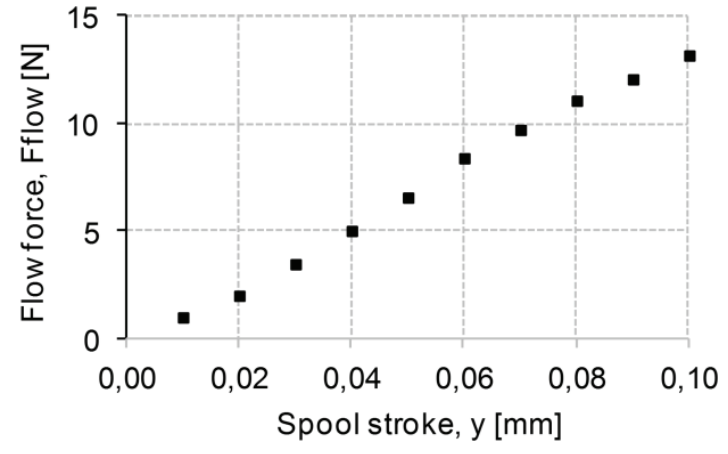

Figure 15 Measured flow force results
The maximal value of the flow force is achieved at a spool stroke of $0,1 \mathrm{~mm}$. The simulation results show how the inlet angle $\alpha$ affects the flow forces at different spool strokes. The minimum axial flow force at a maximum spool opening of $y=0,1 \mathrm{~mm}$ is achieved for an inlet angle of $30^{\circ}$ (Fig. 16d and Fig. 17). This reduces the flow force by approximately $33 \%$, from $12,8 \mathrm{~N}$ to $8,5 \mathrm{~N}$.

The comparison of the simulated and measured results at a maximal spool stroke of $0,1 \mathrm{~mm}$ and at different values of the inlet angle is presented in Fig. 17. It is obvious from the results that the minimal value of the flow force is achieved at the inlet angle of $30^{\circ}$.
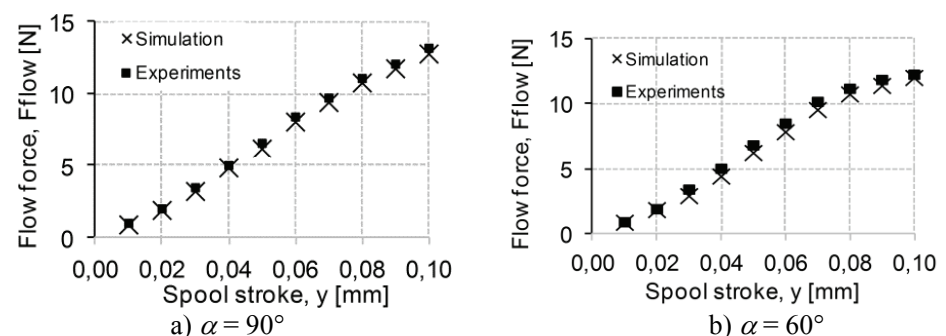

b) $\alpha=60^{\circ}$

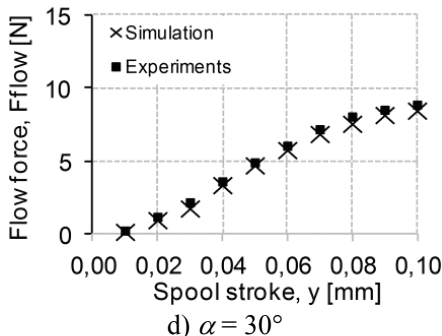

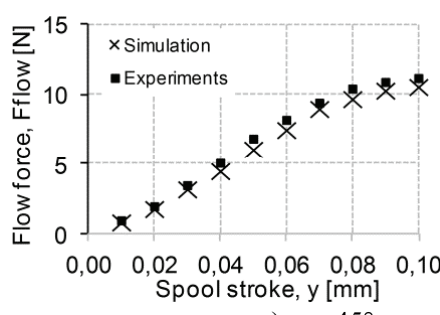

c) $\alpha=45^{\circ}$

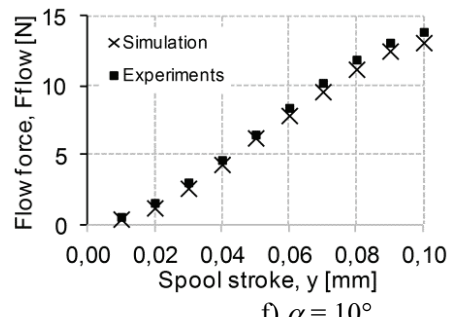

Figure 16 Comparison of the simulated and measured flow force at different inlet angles,a) $90^{\circ}$, b) $60^{\circ}$, c) $45^{\circ}$, d) $30^{\circ}$, e) $20^{\circ}$ and f) $10^{\circ}$ 
The influence of the inlet pressure on the flow force can be seen from Fig. 18. The simulation analysis has also been performed for different inlet pressures of 25, 20 and $10 \mathrm{MPa}$ at a constant pressure drop of 2,5 $\mathrm{MPa}$ per metering edge. The results from Fig. 18 also take into account the increase of the force needed for the plastic deformation of the O-ring seals (around $6 \%$ for a $10 \mathrm{MPa}$ increase). The seals are extra deformed under high pressure, which results in increased measured force. The flow force is slightly higher at a higher inlet pressure (see Fig. 18). A major variation of the force at different inlet pressures can be seen at a $100 \%$ spool stroke, which corresponds to $y=0,1 \mathrm{~mm}$.

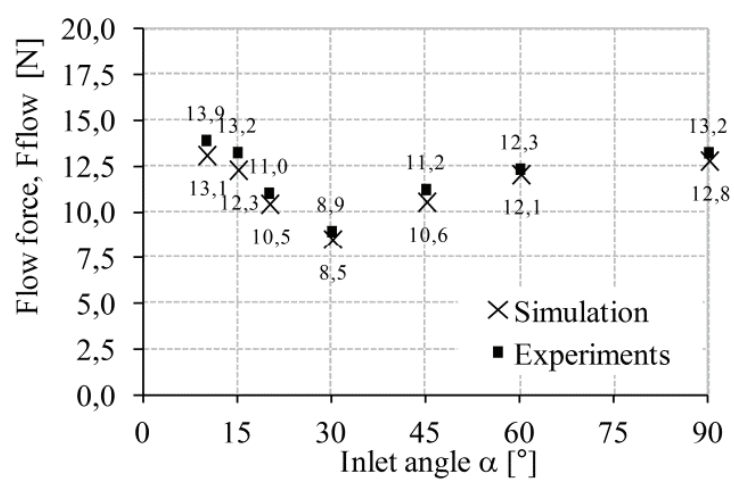

Figure 17 Flow force as a function of the inlet angle $\alpha$

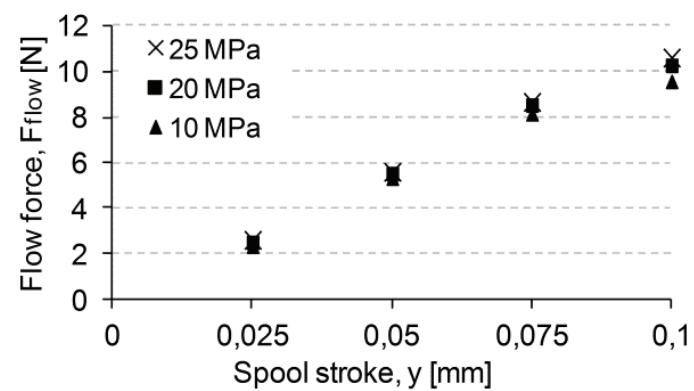

Figure 18 Flow force as a function of the spool stroke at different inlet pressures

\section{Conclusions}

The main goal of this research was to analyze some possible CFD simulation and experimental methods for the reduction of axial static flow forces in hydraulic sliding-spool and small on/off seat valves to a minimum. The CFD simulation research work was performed by using the simulation tool Ansys CFX. An appropriate design of the hydraulic valve housing and the piston has been used in such a way that the flow stream of the fluid through the valve has caused minimal axial static forces.

In both valves, in the sliding-spool as well as in the seat valve, the maximum axial flow forces have been reduced by approximately $33 \%$ with very convenient flow-force characteristics. Consequently, this result makes the use of low-power actuators for the control of directly actuated valves possible even for a higher hydraulic power.

For the sliding-spool valve, only the CFD simulation and optimization of the axial flow forces have been performed. The starting point for this research was the study in the article of Herakovic [4], in which all specific geometrical features and a detailed study of the experimental optimization of the flow forces in the sliding-spool valve have been presented. The results of this research (see Fig. 13) validate the experimental verification of the CFD model of the fluid flow through the entire valve. Since very small openings of the valve's sliding-spool and high turbulences occur during the move of the spool when the situation in the fluid flow through the opening is the most critical the model »k-kl-omega« has been proven to give the best results. The meshing also influenced the accuracy of the CFD model, where the number of 1 million mesh elements gave the best results. We can conclude that the existing CFD model of the sliding-spool valve can be used for further optimization and the development of a new valve.

The study of the small seat valve led to modifications of the inlet angle $\alpha$ of the sliding spool. It showed that it is possible to reduce the flow force in the valve and to eliminate the undesirable non-linear digressive flow-force characteristics by implementing simple geometrical modifications of the spool. Finally, the optimal inlet angle of the spool was found to be $30^{\circ}$ where the flow force was minimal.

The best fit of the simulated and measured flow force curves is achieved by using the k- $\omega$ based shear-stresstransport (SST) simulation model. The meshing parameters used in the model simulation also have significant influence on the simulation results and the simulation procedure. The best fit with the measured results (maximal deviation is around $3 \%$ ) was achieved by using a high resolution mesh for all spool surfaces and in the control edge area (resolution of $0,025 \mathrm{~mm}$ and 0,01 $\mathrm{mm}$ at metering edge area, over 2 million mesh elements).

Future research will be oriented toward further optimization of the spool geometry to include other influence parameters which affect the flow force, such as the outlet angle $\beta$, gap size, geometry of the outlet pocket, etc.

\section{Acknowledgements}

We would like to thank the Research and Development Agency ARRS of the Republic of Slovenia for the financial support of the research project.

\section{References}

[1] Jocanović, M.; Šević, D.; Karanović, V.; Beker, I.; Dudić, $\mathrm{S}$. Increased efficiency of hydraulic systems through reliability theory and monitoring of system operating parameters. // Strojšnik Vestnik-Journal of Mechanical Engineering. 58, 4(2012), pp. 281-288. DOI: 10.5545/svjme.2011.084

[2] Backé, W. Grundlagen der Ölhydraulik. Umdruckzur Vorlesung, 8. Auflage, 1992.

[3] Herakovič, N. Die Untersuchung der Nutzung des Piezoeffektes zur Ansteuerung fluidtechnischer Ventile. Dissertation, RWTH Aachen, 1995.

[4] Herakovič, N. Flow Force Analysis in a Hydraulic SlidingSpool Valve. // Strojarstvo. 51, 6(2009), pp. 555-564.

[5] Engel, H. J. Reibung zwischen Schieberkolben und Buchse. // O+P "Olhydraulik und Pneumatik". 11(1976).

[6] Feigel, H. J. Strömungskraftkompensation in direktgesteuerten elektrohydraulischen Stetigventilen. Dissertation, RWTH Aachen, 1992. 
[7] Tatar, H. Störkräfte bei elektromagnetisch betätigten Wegeventilen. Dissertation, RWTH Aachen, 1974.

[8] Beackon, T. E. Hydrodynamic Forces on Hydraulic Piston Valves. // Engineering. 1957.

[9] Blackburn, J. F.; Lee, S. Y. Contribution Hydraulic Control, Steady-State Axial Forces on Control-Valve Pistons. // ASME, 1952.

[10] Clark, R.N. Compensation of Steady-state Flow Forces in Spool Type Hydraulic Valves. // ASME, 1957.

[11] Latour, C. Entwicklung und Untersuchung strömungskraftreduzierender Maßnahmen in 2-Wege-Einbauventilen. // O+P "Ölhydraulik und Pneumatik". 38, 1-2(1994).

[12] Backé, W. Möglichkeiten zur Kompensation von Reaktionskräften an Steuerelementen hydraulischer Kreisläufe. Industrie-Anzeiger, 1961.

[13] Baghalian, S.; Bonakdari, H.; Nazari, F.; Fazli, M. ClosedForm Solution for Flow Field in Curved Channels Comparison with Experimental and Numerical Analyses and Artificial Neural Network. // Engineering Application of Computational Fluid Mechanics. 6, 4(2012), pp. 514526.

[14] Vosoughifar, H. R.; Dolatshahz, A.; Shokouhii, S.K.S.; Nezhadi, S.R.H. Evaluation of Fluid Flow over Stepped Spillways Using the Finite Volume Method as a Novel Approach. // Journal of Mechanical Engineering. 59, 5(2013), pp. 301-310.

[15] Amirante, R.; Moscatelli, P.G.; Catalano, L.A. Evaluation of the flow forces on a direct (single stage) proportional valve by means of a computational fluid dynamic analysis. // Energy Conversion and Management. 48(2007), pp. 942953.

[16] Schuster, G. CFD-gestützte Maßnahmen zur Reduktion von Strömungskraft und Kavitation am Beispiel eines hydraulischen Schaltventils. Dissertation, RWTH Aachen, Shaker Verlag, Germany, 2005.

[17] Reichart, M. Development of High-Response PiezoServovalves for Improved Performance of Electrohydraulic Cylinder Drives. Dissertation, RWTH Aachen, Germany, 2010.

[18] Muhasilovic, M.; Duhovnik, J. CFD-Based Investigation of the Response of Mechanical Ventilation in the Case of Tunnel-Fire. // Journal of Mechanical Engineering. 58, 3(2012), pp. 183-190.

[19] Tič, V.; Lovrec, D. Air-release and Solid Particles Sedimentation Processwithin a Hydraulic Reservoir. // Tehnički Vjesnik- Technical Gazette. 20, 3(2013), pp. 407412.

[20] Mihalić, T.; Medić, S.; Kondić, Ž. Improving Centrifugal Pump by Adding Vortex Rotor. // Tehnički VjesnikTechnical Gazette. 20, 2(2013), pp. 305-309.

[21] Blackburn, J. F. Fluid Power Control. // M. I. T. Press, 1960.

[22] Čeh, M. Optimization of axial flow force in a hydraulic sliding spool valve by using simulation (in Slovenian). // BSc thesis, University of Ljubljana, Faculty of Mechanical Engineering, 2010.

[23] Anderson, A. G.; Andreasson, P.; Lundström, T. S. CFDModelling and Validation of Free Surface Flow During Spilling of Reservoir in Down-Scale Model. // Engineering Application of Computational Fluid Mechanics. 7, 1(2013), pp. 159-167.

[24] ANSYS FLUENT 12.0, Theory guide, January. 2009. $\mathrm{http} / / / \mathrm{www}$.ansys.com/Support/Documentation. (11.11.2014).

[25] Savić, V.; Knežević, D.; Lovrec, D.; Jocanović, M.; Karanović, V. Determination of Pressure Losses in Hydraulic Pipeline Systems by Considering Temperature and Pressure. // Strojniški Vestnik-Journal of Mechanical Engineering. 55, 4(2009), pp. 237- 243.

\section{Authors' addresses}

Niko Herakovič, Dr. -Ing., Associate Professor University of Ljubljana,

Faculty of Mechanical Engineering, Aškerčeva 6, 1000 Ljubljana, Slovenia

E-mail: niko.herakovic@fs.uni-lj.si

Jožef Duhovnik, Dr. -Ing., Professor

University of Ljubljana,

Faculty of Mechanical Engineering,

Aškerčeva 6, 1000 Ljubljana, Slovenia

E-mail: joze.duhovnik@fs.uni-lj.si

Marko Šimic, Ph. D., researcher

University of Ljubljana,

Faculty of Mechanical Engineering,

Aškerčeva 6, 1000 Ljubljana, Slovenia

E-mail: marko.simic@fs.uni-lj.si 